\title{
長崎県小値賀島住民の保健行動特性
}

\author{
岩 永 秀子*1

\section{Characteristics of Health Behavior of Inhabitants in Ojika Island, Nagasaki Prefecture}

\author{
Hideko Iwanaga*1 \\ ${ }^{* 1}$ School of Nursing, Tokyo Women's Medical University
}

\begin{abstract}
Preventive health behaviors of inhabitants in Ojika island, Nagasaki and Sagamihara city, Kanagawa were analyzed to determine if regional differences exist by adapting Munakata's Preventive Health Behaivior's Model. Information on the degree of practice of health behaviors, 5 factors affecting the practice of health behaviors (priority of health behavior, awareness of health norm, vulnerability to illness, emotional support network, subjective well-being) and dietary habits were obtained by a survey of 122 persons in Ojika and 149 persons in Sagamihara .

People living in Ojika island, especially those under 50 years of age or having ordinary work, had better health behaviors than those in Sagamihara. Multiple regression analysis revealed that the abovementioned 5 factors accounted for about $30 \%$ of the health behaviors score variation in Ojika island, but only about $10 \%$ of that in Sagamihara. People in Ojika, who had high subjective well-being and gave good health behavior priority, practiced the preventive health behavior well. In particular, the inhabitants in Ojika island felt good subjective well-being in close relationships with their neighbors and practiced good health behavior in preference to their ordinary work.
\end{abstract}

\section{要旨}

本研究は，対象の保健行動変容への有効な支援方法を探るために，保健行動の地域特性 を明らかにすることを目的としている，今回は，農漁村部である長崎県小值賀島住民の保 健行動特性を明らかにするために, 都市部である神奈川県相模原市住民と対比検討した. 調査項目は, 保健行動の実行度, 実行要因(保健行動の優先性, 保健規範意識, 病気に対 する脆弱感，情緒的支援ネットワーク，生きがい)，食生活状況である. 分析対象数は小 值賀 122 人，相模原 149 人であった.

分析の結果以下のことが明らかになった.

1 ) 小值賀島住民は都市部住民より保健行動を実行しており, 特に50歳未満, 有職者で差 がみられた。 小值賀島住民は規則正しい食事をし，夜更かしをさけ，睡眠を十分とって いた。

2 ）小值賀島住民は都市部住民より生活行動の中で保健行動を優先させる態度が強く，ま た生きがいを多くもっていた．特に仕事，地域の人との関わり，宗教をより生きがいと する人の割合が高かった。 
3 ）調査した 5 つの実行要因によって, 小值賀島住民の保健行動実行度の約 $30 \%$ が説明可 能であり，都市部住民に比べ影響が大きかった。小值賀島住民では，他の生活行動より 保健行動を優先させる態度が強い人ほど, 生さがいを多くもっている人ほど, 保健行動 の実行度が高かった。

\section{I . はじめに}

人口の高齢化とともに，生活行動が要因とな る疾患や慢性的な経過をたどる疾患をもちなが ら日常生活を送る人の割合が増加している.

個人の生活行動は，乳幼児期からの生活の中 で，それぞれの地域社会の影響のもとに，主と して親から伝達され，習慣化されたものである. 健康に関する生活行動(保健行動) る, 社会の中 で習慣化された行動であり，家族やその地域の 特性の影響を受けている。したがって，対象の 行動変容を支援するためには，その人の現在の 状態を理解するだけでなく，その人が生活して いる地域の中で受け継がれている考方方や行動 様式を理解することが有用であろら。

これまでにも，特定地域の食生活の実態 1 7) や食生活と身体的健康状態との関連に関する研 究 ${ }^{8 \sim 10)}$ が報告されている. しかし, 地域特性 に着目した食生活以外の生活行動に関する研究 ${ }^{11)}$ や，それに影響する要因に関する行動科学的研 究12,13) は少ない。

本研究は, 対象の保健行動变容を促進する有 効な支援方法を探るために, 保健行動の地域特 性を明らかにすることを目的としている. 今回, その第 1 段階として, 農漁村部である長崎県の 離島, 小值賀島住民の保健行動々その要因の地 域特性を，都市部である神奈川県相模原市住民 と対比することにより明らかにしようと試みた。

\section{II. 研究方法}

\section{1. 調査地域の概要}

小值賀町 (以後, 小値賀) は, 長崎県五島列島 の北部に位置し, 大小17の島からなる. 長崎県 佐世保市から $90 \mathrm{Km}$ の距離にあり, 一日に船便 5 便, 航空便 3 便で九州本土と結ばれている. 人口は 4,187 人, 年齢 3 区分別人口構成は，0～ 14 歳 $17.8 \%, 15$ 2 44 歳 $53.3 \%$, 65歳以上 $28.9 \%$
である(1995年)，産業別就業人口構成は，第 1 次産業 $48.2 \%$, 第 2 次産業 $10.7 \%$, 第 3 次産業 $41.1 \%$ である(1990年). 今回, 小值賀本島 (総 世帯数 1,425$)$ のうち, 漁業・商業地区 (調査対 象世帯数151) と半農半漁地区 (同93) を調査対象 とした。

相模原市 (以後, 相模原) は, 神奈川県の県央 部に位置する首都圈の広域中核都市であり, 人 口は 57 万人を越えている(1995年)。年齢別人口 構成は，0～14歳 $17.9 \% ， 15 ６ 4$ 歳 $75.0 \% ， 65$ 歳以上 $6.9 \%$ である $(1990$ 年, $0.2 \%$ は年齢不詳). 産業別就業人口構成は，第 1 次産業 $0.8 \%$, 第 2 次産業 $38.6 \%$, 第 3 次産業 $60.6 \%$ である $(1990$ 年). 今回, 相模原市内で最大の駅から半径 2 $\mathrm{Km}$ 内にある都市型住宅地 (調查対象世帯数 388 ) を調査対象とした。

\section{2. 調查方法と時期}

調査対象地区の全世帯を直接訪問し, 調查へ の協力を依頼した．同意を得られた世帯に無記 名自記式の調查票を配布した。調查内容に食品 の摂取頻度を含むため, 回答はできるだけ食事 作りを担当している方に依頼した。調査票は, 後日調查者が直接訪問, 回収した。調査時期は 1996年 7 月〜 8 月である.

\section{3. 調査内容}

調査項目は, (1)保健行動の実行度, (2)保健行 動の実行要因(他の生活行動に対する保健行動 の優先性の強さ, 保健規範意識の強さ, 病気一 般に対する脆弱感の強さ, 情緒的支援ネットワー クの強さ，生きがいの多さ), (3)最近一ヶ月間 の食生活状況，とした。調査項目の(1)と(2) 宗像 ${ }^{14)}$ が開発した測定用具を用いた。本研究 に抢ける信頼性係数(クローンバック $\alpha$ ) は, 0.60 〜0.85であった. 食生活状況としては, 先行研 究1,15 18) を参考に, 各種食品の摂取頻度と食 
事スタイル(家族そろっての食事頻度, 交際上 の飲食頻度, 夜食・外食・調理済及食品による 食事頻度など）を，選択肢を設けて調査した。

\section{4. 分析方法}

保健行動の実行度と実行要因は, 宗像 ${ }^{14)}$ に 従って得点化し，それぞれ「保健行動得点(得 点範囲 $0 \sim 21$ 点) 」「優先性得点(同 $0 \sim 4$ 点) 」

$\lceil$ 規範意識得点(同 $0 \sim 6$ 点)」「脆弱感得点 (同 $0 \sim 6$ 点) 」「支援得点(同 $0 \sim 10$ 点) 」「生きが い得点(同 $0 \sim 9$ 点)」とした. 各得点の平均値 の地域差を $\mathrm{t}$ 検定により分析した。 また質問項 目別に肯定回答率の地域差を $\chi^{2}$ 検定により分 析した. 肯定回答とは, 保健行動では「はい」, 保健行動の優先性, 保健規範意識, 病気に対す る脆弱感では「大いにそらである」又は「まあ そらである」, 生きがいでは「生さがいである」， 情緒的支援ネットワークでは「いる」の回答を さす.

また，保健行動に及ぼす各実行要因の独自の 影響度を明らかにするために，「保健行動得点」 を基準変数, 各実行要因得点を説明変数とし, 重回帰分析(全变数を一括投入)を行った.

食生活状況は，回答の選択肢を再カテゴリー 化し，回答の分布の地域差を分析した. データ 分析には，統計パッケージ「HALBAU」を使 用した。統計的有意性の検定においては， $\mathrm{p}<$ 0.05 を有意」, $0.05 \leqq \mathrm{p}<0.1$ を「傾向あり」 とした。

\section{III. 結果}

\section{1. 対象者の属性}

有効回答者の属性を表 1 亿示した. 平均年齢 は, 小值賀 $57.4 \pm 14.8$ 歳, 相模原 $51.2 \pm 12.1$ 歳 であり, 小值賀の方が高かった $(\mathrm{p}<0.01)$. 性 別は，小值賀の $77.1 \%$, 相模原の $92.0 \%$ が女性 であり, 小值賀の方が女性の割合が低かった $(\mathrm{p}<0.01)$. 有職者の割合は，小值賀 $51.6 \%$, 相模原 $44.3 \%$ であり, そのらち第 1 次産業従事 者は, 小值賀 $42.9 \%$, 相模原 $0 \%$ であった.

\section{2. 保健行動の実行度の地域差}

「保健行動得点」の平均値は，小值賀が相模

\section{表 1 調査票の回収状況と分析対象者の属性}

\begin{tabular}{|c|c|c|c|}
\hline & 小值 賀 & 相 模 原 \\
\hline \multirow{2}{*}{\multicolumn{2}{|c|}{ 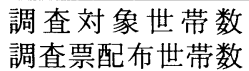 }} & 244 & 388 \\
\hline & & 132 & 154 \\
\hline \multicolumn{2}{|c|}{ 有 効 回 答 数 } & 122 & 149 \\
\hline & 平 均（歳） & $57.36 \pm 14.84$ & $51.19 \pm 12.13$ \\
\hline \multirow{5}{*}{ 齢 } & 20 & $3(2.5)$ & $7(4.7)$ \\
\hline 年 & 30 & $15(12.3)$ & $19(12.7)$ \\
\hline & 40 & $24(19.7)$ & $38(25.5)$ \\
\hline & 50 & $7(13.9)$ & $42(28.2)$ \\
\hline & 60 & $31(25.4)$ & $29(19.5)$ \\
\hline & 70 & $26(21.3)$ & $11(7.4)$ \\
\hline & 80 & $5(4.1)$ & $0(0.0)$ \\
\hline & 回 & $1(0.8)$ & $3(2.0)$ \\
\hline \multicolumn{2}{|c|}{ 平均同居人数 (人) } & $3.09 \pm 1.75$ & $3.31 \pm 1.26$ \\
\hline \multirow{3}{*}{$\begin{array}{l}\text { 性 } \\
\text { 別 }\end{array}$} & 男 & $27(22.1)$ & $9(6.0)$ \\
\hline & 女 & $94(77.1)$ & $137(92.0)$ \\
\hline & 回 & $1(0.8)$ & $3(2.0)$ \\
\hline \multirow{3}{*}{$\begin{array}{l}\text { 職 } \\
\text { 銖 } \\
\text { 有 } \\
\text { 無 } \\
\end{array}$} & 職 & $63(51.6)$ & $66(44.3)$ \\
\hline & 職 & $58(47.6)$ & $77(51.7)$ \\
\hline & 無 回 & $1(0.8)$ & $6(4.0)$ \\
\hline 職 & 1 次 産 業 & $27(42.9)$ & $0(0.0)$ \\
\hline 種 & $2 \cdot 3$ 次産業 & $36(57.1)$ & $66(100.0)$ \\
\hline
\end{tabular}

(人 $(\%))$

原より高かった(表 2 ). 性別でみると, 女性で は同様の結果であったが，男性では差はなかっ た. 年齢別では, 両地域とも年齢が高くなるに つれて保健行動得点が高くなっていた．40歳代 では小值賀の方が高く，30歳代でも同様の傾向 がみられた、職業の有無別にみると, 有職者で は小值賀の方が高かった(表 3 ). データは示し ていないが, 第 $2 \cdot 3$ 次産業従事者に限って比 較した場合も同様の結果であった。無職者では 差はみられなかった。

保健行動の質問項目別肯定回答率を表 4 亿示 した。食事に関する保健行動では，「規則正し い食事」「色の濃い野菜の摄取」の肯定回答率 は，小値賀の方が高かった。「海草類の摂取」 「大豆製品の摂取」「飲酒をひかえる」「動物性 脂肪の摂取をひかえる」でも，小值賀の方が高 い傾向にあった．年齢別にみると，50歳以上で は両地域間で差はみられなかった. 30〜40歳代 では，「毎日の野菜拱取」「色の濃い野菜の摂取」 「海草類の摂取」「動物性の脂肪摂取をひかえる」 の項目で，小値賀の肯定回答率が高い傾向にあっ た。 
休息に関する保健行動では，「十分な睡眠」 と「夜ふかしをしない」の肯定回答率は小値賀 の方が高かった．年齢別にみると，40歳代では

「十分な睡眠」，60歳代では「夜ふかしをしな い」の項目で, 小值賀の方が高い肯定回答率を 示した。

全体でみた場合には，両地域間で活動・運動 に関する保健行動の肯定回答率に差はみられな かった．年齢別にみると，30歳代で，「手軽な 運動をする」「野外運動をする」の項目で小值 賀の肯定回答率が高かった.

\section{3. 保健行動の実行要因の地域差(表 2,3，4)}

「優先性得点」の平均值は, 小值賀の方が高 く，男女ともにその傾向がみられた．年齢別で

\section{表 2 保健行動得点と実行要因得点の平均値の地域差}

\begin{tabular}{|c|c|c|c|}
\hline 項 & 目 & 小值 賀 & 相 模 原 \\
\hline \multirow[b]{2}{*}{ 保健行動 } & 全 体 & $14.57 \pm 4.10^{*}$ & $13.54 \pm 3.76$ \\
\hline & $\begin{array}{l}30 \text { 歳代 } \\
40 \text { 歳代 } \\
50 \text { 歳代 } \\
60 \text { 歳代 } \\
70 \text { 歳代 }\end{array}$ & $\begin{array}{l}12.80 \pm 4.04^{+} \\
13.96 \pm 3.21^{*} \\
13.59 \pm 4.82 \\
15.13 \pm 4.48 \\
16.58 \pm 2.98\end{array}$ & $\begin{array}{l}10.74 \pm 3.05 \\
11.95 \pm 3.78 \\
13.50 \pm 3.19 \\
15.93 \pm 2.74 \\
17.73 \pm 2.83\end{array}$ \\
\hline \multirow[b]{2}{*}{$\begin{array}{l}\text { 保健行動の } \\
\text { 優先性 }\end{array}$} & 全 体 & $1.11 \pm 1.31^{*}$ & $0.76 \pm 1.02$ \\
\hline & $\begin{array}{l}30 \text { 歳代 } \\
40 \text { 歳代 } \\
50 \text { 歳代 } \\
60 \text { 歳代 } \\
70 \text { 歳代 }\end{array}$ & $\begin{array}{l}0.27 \pm 0.46 \\
0.71 \pm 1.00 \\
0.59 \pm 0.94 \\
1.67 \pm 1.45 \\
1.62 \pm 1.44\end{array}$ & $\begin{array}{l}0.21 \pm 0.42 \\
0.61 \pm 0.68 \\
0.62 \pm 0.91 \\
1.31 \pm 1.31 \\
1.55 \pm 1.51\end{array}$ \\
\hline \multirow[b]{2}{*}{$\begin{array}{l}\text { 保健規範意 } \\
\text { 識 }\end{array}$} & 全 体 & $3.00 \pm 1.67$ & $2.77 \pm 1.73$ \\
\hline & $\begin{array}{l}30 \text { 歳代 } \\
40 \text { 歳代 } \\
50 \text { 歳代 } \\
60 \text { 歳代 } \\
70 \text { 歳代 }\end{array}$ & $\begin{array}{l}3.13 \pm 1.69 \\
2.42 \pm 1.72 \\
3.00 \pm 1.80 \\
3.74 \pm 1.34 * \\
2.73 \pm 1.80\end{array}$ & $\begin{array}{l}2.58 \pm 1.77 \\
2.42 \pm 1.91 \\
3.10 \pm 1.59 \\
2.93 \pm 1.58 \\
3.36 \pm 2.06\end{array}$ \\
\hline \multirow[b]{2}{*}{$\begin{array}{l}\text { 病気一般に } \\
\text { 対する脆弱 } \\
\text { 感 }\end{array}$} & 全 体 & $0.47 \pm 1.05$ & $0.42 \pm 1.00$ \\
\hline & $\begin{array}{l}30 \text { 歳代 } \\
40 \text { 歳代 } \\
50 \text { 歳代 } \\
60 \text { 歳代 } \\
70 \text { 歳代 }\end{array}$ & $\begin{array}{l}0.07 \pm 0.26 \\
0.79 \pm 1.35 \\
0.29 \pm 0.77 \\
0.30 \pm 0.70 \\
0.69 \pm 1.38^{*}\end{array}$ & $\begin{array}{l}0.32 \pm 0.82 \\
0.50 \pm 0.92 \\
0.69 \pm 1.30 \\
0.07 \pm 0.26 \\
0.00 \pm 0.00 \\
\end{array}$ \\
\hline \multirow[b]{2}{*}{$\begin{array}{l}\text { 情緒的支援 } \\
\text { ネットワーク }\end{array}$} & 全 体 & $7.56 \pm 2.94^{*}$ & $8.27 \pm 2.50$ \\
\hline & $\begin{array}{l}\text { 30歳代 } \\
40 \text { 歳代 } \\
50 \text { 歳代 } \\
60 \text { 歳代 } \\
70 \text { 歳代 }\end{array}$ & $\begin{array}{l}8.57 \pm 1.83 \\
7.46 \pm 3.23 \\
7.65 \pm 3.06 \\
6.71 \pm 3.15^{\text {*** }} \\
8.33 \pm 2.46\end{array}$ & $\begin{array}{l}9.16 \pm 1.34 \\
7.74 \pm 2.42 \\
8.10 \pm 3.04 \\
8.76 \pm 1.98 \\
7.73 \pm 2.24\end{array}$ \\
\hline \multirow[b]{2}{*}{ 生きがい } & 全 体 & $4.50 \pm 2.74^{* *}$ & $3.48 \pm 2.29$ \\
\hline & $\begin{array}{l}\text { 30歳代 } \\
40 \text { 歳代 } \\
50 \text { 歳代 } \\
60 \text { 歳代 } \\
70 \text { 歳代 }\end{array}$ & $\begin{array}{l}3.20 \pm 2.86 \\
3.42 \pm 2.55 \\
5.24 \pm 2.80^{*} \\
5.00 \pm 2.38 \\
5.58 \pm 2.67\end{array}$ & $\begin{array}{l}2.95 \pm 1.22 \\
2.92 \pm 2.28 \\
3.48 \pm 2.34 \\
4.41 \pm 2.46 \\
4.36 \pm 2.62\end{array}$ \\
\hline
\end{tabular}

は地域差はなかった、職業の有無別では, 有職 者で同様の傾向がみられた．質問項目別肯定回 答率は，「仕事がたをっても無理をしない」で 小值賀が高く,「病気になると休養する」でも 同様の傾向がみられた.

「規範意識得点」の平均值には，全体では差 はなかったが，年齢別では，60歳代で小值賀の 万が高かった，小值賀の方が「寝たきり老人の 世話は家族・親族がする」と思っている人の割 合が高く，年齢別でも60歳代で差がみられた. 逆に,「主婦は病気になれない」の肯定回答率 は，小值賀の方が低かった。

「脆弱感得点」の平均值にも, 有意な地域差 はみられなかった．年齢別に質問項目別肯定回 答率をみると，30歳代では「年歯相応の体力が ある」と回答した人の割合が小值賀の方が高かっ た。しかし，60歳代では「病気に対する抵抗力 がある」「丈夫な方で減多に病気にかからない」 「身体には自信がある」で，70歳代では「丈夫 な方で減多に病気にかからない」の各項目で， 小値賀の肯定回答率が低かった。

「支援得点」の平均值は，全体では小値賀の 方が低く，年齢別では60歳代，職業の有無別で は無職者, 性別では女性で, 同様の結果であっ た. 質問項目別にみた場合，「甘えられる人」 がいると回答した人の割合は小值賀の方が低かっ た．年齢別にみると，30歳代で「あなたを信じ 思うようにさせてくれる人」，60歳代で「気持 ちを敏感に察してくれる人」「個人的な気持ち や秘密を打ち明けられる人」「抒互いの考并や

\section{表 3 職業の有無別にみた保健行動得点と実行要因} 得点の平均値の地域差

\begin{tabular}{|c|c|c|c|}
\hline & 項 & 小 值 賀 & 相 模 原 \\
\hline \multirow{6}{*}{$\begin{array}{l}\text { 有 } \\
\text { 職 } \\
\text { 者 }\end{array}$} & 保 健 行 動 & $13.75 \pm 4.50 *$ & $12.11 \pm 3.82$ \\
\hline & 保健行動の優先性 & $0.92 \pm 1.14^{+}$ & $0.59 \pm 0.89$ \\
\hline & 保健規範意識 & $2.70 \pm 1.76$ & $2.96 \pm 1.69$ \\
\hline & 病気一般に対する脆弱感 & $0.41 \pm 0.91$ & $0.52 \pm 1.09$ \\
\hline & 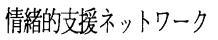 & $8.33 \pm 2.29$ & $7.99 \pm 2.72$ \\
\hline & 生きが い & $4.97 \pm 2.90^{* * *}$ & $3.23 \pm 2.19$ \\
\hline \multirow{6}{*}{$\begin{array}{l}\text { 無 } \\
\text { 職 } \\
\text { 者 }\end{array}$} & 保 健 行 動 & $15.31 \pm 3.56$ & $14.55 \pm 3.29$ \\
\hline & 保健行動の優先性 & $1.26 \pm 1.46$ & $0.91 \pm 1.11$ \\
\hline & 保健規範意識 & $3.31 \pm 1.54$ & $2.57 \pm 1.75$ \\
\hline & 病気一般に対する脆弱感 & $0.53 \pm 1.18$ & $0.35 \pm 0.94$ \\
\hline & 情緒的支援ネットワーク & $6.74 \pm 3.33^{* *}$ & $8.74 \pm 1.96$ \\
\hline & 生きがい & $3.97 \pm 2.50$ & $3.81 \pm 2.35$ \\
\hline
\end{tabular}




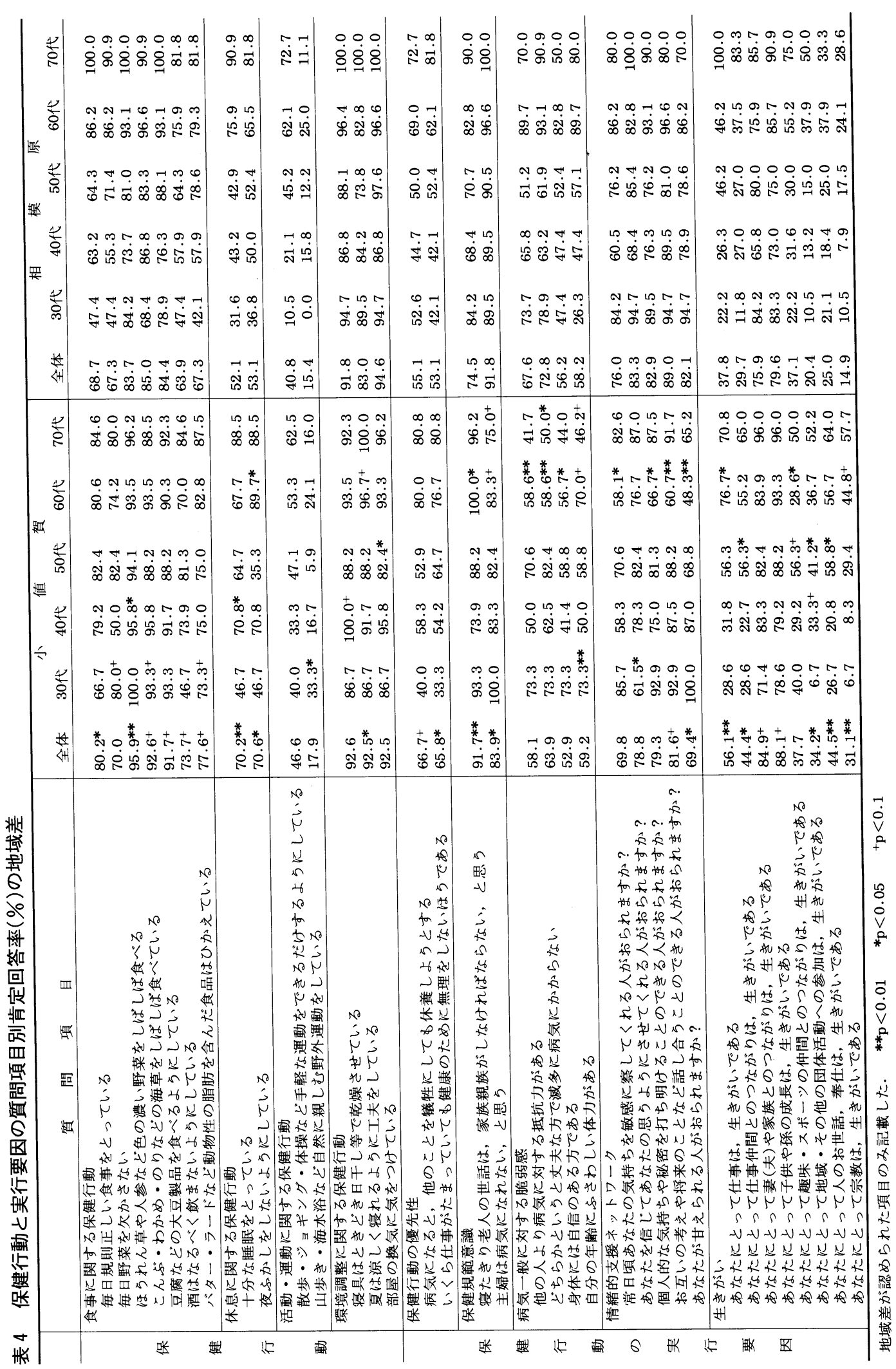


将来のことを話し合える人」「甘えられる人」 がいると回答した人の割合は小值賀の方が低かっ た。

「生きがい得点」の平均值は，小值賀の方が 高く, 男女ともに同様の結果であった。両地域 とも年齢が高くなるにつれ「生きがい得点」の 平均值も高くなる傾向があるが，50歳代では地 域差がみられ，小値賀の方が高かった．職業の 有無別にみると, 有職者では小值賀の方が高い が，無職者では地域差はなかった．質問項目別 肯定回答率をみると, 小值賀は相模原より「仕 事」「仕事仲間とのつながり」「地域・その他の 団体活動への参加」「人のお世話・奉仕」「宗教」 を生きがいと思っている人の割合が高かった。 年齢別にみた場合， 50 歳代では「仕事仲間との つながり」「地域・その他の団体活動への参加」 「人のお世話・奉仕」，60歳代では「仕事」を 生きがいとする人の割合は小值賀の方が高かっ た。逆に60歳代では「趣味・スポーツの仲間と のつながり」を生きがいとする人の割合が小值 賀の方が低かった。

\section{4 . 保健行動の実行度に対する実行要因の影響}

重回㷌分析の結果 (図 1 )，小值賀では，「保 健行動得点」に対する「優先性」「規範意識」 「生きがい」の各得点の標準偏回帰係数 $(\beta)$ は, それぞれ $0.17,0.23,0.33$ であり，「保健行動得 点」に有意な影響を及ぼしていた。決定係数は 0.30 であった. 年齢別にみると, 50 歳未満では 「優先性得点」 $(\beta=0.34)$ が，50歳以上では 「規範意識得点」( $\beta=0.29) 「$ 生きがい得点」 ( $\beta=0.42)$ が,「保健行動得点」へ有意な影響 を及ぼしていた。性別にみると，女性では全体 と同様であり, 男性では「生きがい得点」( $\beta$ $=0.60$ )のみ有意な影響を示した.

一方相模原では，「保健行動得点」に有意な 影響を示した説明変数は，「優先性」と「生き がい」の両得点であり，それぞれの標準偏回帰

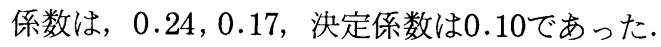
50 歳未満では,「規範意識得点」は「保健行動 得点」へ負の方向に影響していた．50歳以上で は，有意な影響を及ぼしていた要因はみられな かった。

\begin{tabular}{|c|c|c|c|}
\hline & & 小 & 模 \\
\hline \multicolumn{2}{|c|}{ 全 } & $\begin{array}{l}\begin{array}{l}\text { 保健行動の優先性 } \\
\text { 保健規範意識 } \\
\text { 病気一般に対する脆弱感 } 0.230^{* * * \rightarrow} \text { 保健行動 } \\
\text { 情緒的支援ネットワーク } \\
\text { 生さがい }\end{array} \mathrm{R}^{2}=0.299 * * \\
\end{array}$ & $\begin{array}{l}\text { 保健行動の優先性 } \\
\text { 保健規範意識 } \\
\text { 病気一般に対する脆弱感 } \\
\text { 情緒的支援ネットワーク } \\
\text { 生きがい }\end{array}$ \\
\hline 別 & 性 & $\begin{array}{l}\text { 保健行動の優先性 } \\
\text { 保健規範意識 } \\
\text { 病気一般に対する脆弱感 } \\
\text { 情緒的支援ネットワーク } \\
\text { 生きがい }\end{array}$ & $\begin{array}{l}\text { 保健行動の優先性 } \\
\text { 保健規範意識 } \\
\text { 病気一般に対する脆弱感 } \\
\text { 情緒的支援ネットワーク } \\
\text { 生きがい }\end{array}$ \\
\hline 年 & $\begin{array}{l}50 \\
\text { 歳 } \\
\text { 末 } \\
\text { 満 }\end{array}$ & $\begin{array}{ll}\text { 保健行動の優先性 } & 0.341^{*} \\
\text { 保健規範意識 } & \text { 保健行動 } \\
\text { 病気一般に対する脆弱感 } & \mathrm{R}^{2}=0.269 * \\
\text { 情緒的支援ネットワーク } & \\
\text { 生きがい } & \\
\end{array}$ & $\begin{array}{l}\text { 保健行動の優先性 } \\
\text { 保健規範意識 } \\
\text { 病気一般に対する脆弱感 } \\
\text { 情緒的支援ネットワークーク } \\
\text { 生さがい }\end{array}$ \\
\hline 別 & $\begin{array}{l}50 \\
\text { 歳 } \\
\text { 以 } \\
\text { 上 }\end{array}$ & $\begin{array}{l}\text { 保健行動の優先性 } \\
\text { 保健規範意識 } \\
\text { 病気一般に対する脆弱感 } \\
\begin{array}{l}\text { 情緒的支援ネットワーク } \\
\text { 生きがい }\end{array} \quad \mathrm{R}^{2}=0.321^{* *} \\
\end{array}$ & $\begin{array}{l}\text { 保健行動の優先性 } \\
\text { 保健規範意識 } \\
\text { 病気一般に対する脆弱感 } \\
\text { 情緒的支援ネットワーク } \\
\text { 生きがい }\end{array}$ \\
\hline
\end{tabular}

図 1 保健行動におよぼす保健行動実行要因の影響 


\section{5. 食生活状況の地域差}

小值賀と相模原の食品摂取頻度と食事スタイ ルの比較を表 5 に示した.

主食では, 小值賀の方がご飯の摄取頻度は高 く，パンの摄取頻度は低かった．主菜では，小 值賀は魚介類や魚の加工品を頻回に摂取する人 が多く, 逆に肉の加工品, 乳製品を頻回に摂取 する人が少なかった。肉, 卵, 大豆製品では摂 取頻度に地域差はなかった. 副菜では, 漬け物 の摂取頻度が小值賀が高かったが, 野菜, 海草 など他の副菜食品では地域差はなかった。嗜好 品では, 日本茶は小值賀の方が高く, コーヒー, 紅茶は低かった。

食事スタイルでは，小值賀の方が朝食を毎日 摂取する人が多く，家族がそろって食事する頻 度も高かった．仕事に関する交際上の飲食頻度 に地域差はみられなかったが, 友人との交際上 の飲食頻度, 外食や調理済み食品による食事の
頻度は，小值賀の方が低かった.

\section{IV. 考察}

慢性疾患の増加に伴い, 施設内だけでなく, 自宅で療養生活を送る人が増加し, 看護の活動 領域がますます地域社会の中へ拡がっていくこ とが予想される.施設内での看護においても， 対象のそれまでの日常生活の把握が不可欠であ るが，自宅での生活支援においてはなおさらで ある. 対象の行動変容を効果的に支援するため には, 各地域で受け継がれている保健行動に関 する考方や行動様式を理解することが有用で あろら。

今回, 農漁村部である長崎県小值賀島住民の 保健行動の地域特性を, 都市部住民の保健行動 と対比し検討した.

\section{表 5 食生活状況の地域差}

\begin{tabular}{|c|c|c|c|c|c|c|}
\hline & & & 全 体 & 50歳未満 & 50歳以上 & 小值賀の方が \\
\hline \multirow[b]{2}{*}{ 食 } & 主 食 & $\begin{array}{l}\text { ご飯 } \\
\text { パン } \\
\text { 麵 }\end{array}$ & $\begin{array}{l}* * \\
* *\end{array}$ & $\begin{array}{l}* * \\
*\end{array}$ & $\begin{array}{l}* * \\
* *\end{array}$ & $\begin{array}{l}\text { 食べる } \\
\text { 食べない } \\
\text { 食べない }\end{array}$ \\
\hline & 主菜 & $\begin{array}{l}\text { 1. 肉 } \\
2 . \text { 肉の加工品 } \\
3 . \text { 魚介類 } \\
4 . \text { 魚の加工品 } \\
5 . \text { 卵 } \\
6 . \text { 大豆製品 } \\
7 . \text { 牛乳類 } \\
\end{array}$ & $\begin{array}{l}* * \\
* * \\
* * \\
*\end{array}$ & + & $\begin{array}{l}+ \\
* * \\
* *\end{array}$ & $\begin{array}{l}\text { 食べない } \\
\text { 食べない } \\
\text { 食べる } \\
\text { 食べる } \\
\text { 飲まない }\end{array}$ \\
\hline 取 & 食副菜 & $\begin{array}{l}\text { 8. } \text { いも類 } \\
9 . \text { 緑黄色野菜 } \\
\text { 10. 淡黄色野菜 } \\
\text { 11. 海草 } \\
\text { 12. きのこ類 } \\
\text { 13. 漬物 } \\
\text { 14. 果物類 } \\
\end{array}$ & $\begin{array}{l}* * \\
* *\end{array}$ & & $\begin{array}{l}* * \\
* *\end{array}$ & $\begin{array}{l}\text { 食べない } \\
\text { 食べない } \\
\text { 食べる }\end{array}$ \\
\hline & 嗜好 品 & $\begin{array}{l}\text { 15. 日本茶 } \\
\text { 16. コーヒー, 紅茶 } \\
\text { 17. 清涼飲料 }\end{array}$ & $\begin{array}{l}* * \\
* *\end{array}$ & $\begin{array}{l}* * \\
*\end{array}$ & + & $\begin{array}{l}\text { 食む } \\
\text { 飲むない }\end{array}$ \\
\hline & 朝 食 & 摄取頻度 & $*$ & + & & 食べる \\
\hline $\begin{array}{l}\text { 食 } \\
\text { 事 }\end{array}$ & $\begin{array}{l}\text { 家族での } \\
\text { 食事頻度 }\end{array}$ & $\begin{array}{l}\text { 朝食 } \\
\text { 夕食 }\end{array}$ & $\begin{array}{l}* * \\
* *\end{array}$ & $\begin{array}{l}* * \\
* *\end{array}$ & $\begin{array}{l}* * \\
* *\end{array}$ & $\begin{array}{l}\text { 一緒に食べる } \\
\text { 一緒に食べる }\end{array}$ \\
\hline $\begin{array}{l}\text { ス } \\
\text { タ }\end{array}$ & $\begin{array}{l}\text { 交際上の } \\
\text { 飲食頻度 }\end{array}$ & $\begin{array}{l}\text { 仕事関係 } \\
\text { 仲間関係 } \\
\end{array}$ & $*$ & & $*$ & 食べない \\
\hline $\begin{array}{l}1 \\
ル\end{array}$ & $\begin{array}{l}\text { その他の } \\
\text { 食事頻度 }\end{array}$ & $\begin{array}{l}\text { 夜食 } \\
\text { 外食 } \\
\text { 調理済み食品 } \\
\end{array}$ & $\begin{array}{l}* * \\
* *\end{array}$ & $\begin{array}{l}* * \\
*\end{array}$ & $\begin{array}{l}* * \\
* *\end{array}$ & $\begin{array}{l}\text { 食べない } \\
\text { 食べない }\end{array}$ \\
\hline
\end{tabular}

$* * \mathrm{p}<0.01 \quad * \mathrm{p}<0.05 \quad+\mathrm{p}<0.1$ 


\section{1 、小值賀島住民の保健行動の地域特性}

小值賀住民は都市部住民より保健行動を実行

しており, 特に食事, 休息に関する保健行動に おいてその傾向がみられた。

食事に関する保健行動では, 都市部住民に比 べ小值賀住民は, 毎日規則的に食事し, 野菜, 海草, 大豆製品を頻回に拱取し，酒や脂肪の多 い食品の摂取をひかえていた．最近一ヶ月の食 生活の調查結果でる, 朝食を毎日掑取する人の 割合が高く,「毎日の規則正しい食事」の肯定 回答率の高さを裏付けていた。主食, 主菜, 嘫 好食品の掑取頻度から相対的に考光ると，小值 賀では, ご飯, 魚, 日本茶を主とする日本の伝 統的な食事内容であり, 都市部では, パン, 肉, コーヒー・紅茶を比較的多食する近代的・西洋 的な食事内容であることが伺われる.これは京 都府下の都市部は近代型食パターン, 農漁村部 は伝統的な食パターンであったという報告1) と 一致している. 環境の都市化は主食の拱取状況 飞強い影響を与える19) といわれ，今回の主食 摂取頻度の差も, 農漁村部であり, 離島である 小値賀の地理的要因や流通状況に伴う食品の入 手のしやすさなどの地域特性を反映していると 考穴られる. 小值賀住民の調理済及食品, 出前, 外食による食事頻度は都市部住民と比べて低く， これは食事内容だけでなく，採䭒行動や調理行 動飞も地域特性があることを示している．採慨 行動之調理行動は, 流通業の肥大化, 加工食品 の大量生産, 外食産業の発達によって影響を受

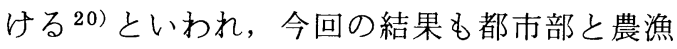
村部の流通や産業などの地域特性を反映したも のであろう．年齢別にみると，50歳代以上では 両地域の食事に関する保健行動に差は認められ ず，30歳代，40歳代で地域差がみられた．都市 部でも農漁村部でも高齢になると健康維持のた めに食事に気を配るが，小値賀住民は比較的若 い時期から健康的な食生活を行っていることを 示唆している. 特に育児期にある $30 \sim 40$ 歳代で 小值賀住民は食事に関するよい保健行動を行っ ており，これは自然に次世代伝伝られていく と予想される. 今後更に食生活状沉を詳細に把 握し，30〜40歳代をはじめとして, 健康的な食 行動を支援することが有効であると考光る。
休息に関する保健行動については，小值賀住 民は夜更かしをせず，十分に睡眠をとっている 人の割合が高かった．生活時間は大きく拘束時 間, 生理的生活時間, 文化的自由時間炕分けら れる ${ }^{21)}$ が，小値賀住民は，生理的生活時間を 十分に確保できているといえよう。これには， 通勤等に伴う拘束時間, 趣味や交際などに費や す文化的自由時間の配分が影響していると考兄 られる．小值賀では，通勤等に伴ら拘束時間は 今後も增加しないと予想され，文化的自由時間 をより活用するような看護的関わりが有効であ ろう。

\section{2. 小值賀島住民の保健行動実行要因の地域特}

性

今回, 保健行動の実行に影響を及济す要因と して調査した 5 つの要因のらち, 平均得点に地 域差がみられたのは, 保健行動の優先性, 情緒 的支援ネットワーク，生きがいであった。

保健行動の優先性は，小值賀住民の方が高く， 小值賀住民は，健康に注意を払い，仕事などの 生活行動より健康を維持するための行動を優先 させる態度をより強くもっているといえよう。 特に有職者に抒いてその傾向がみられ，両地域 の仕事のあり様が住民の保健行動の優先性飞影 響していると考兄る．都市部では，大・中企業 飞勤務する人が比較的多く，また職場と住宅が 遠く通勤時間が長いため, 保健行動を優先させ ることができない状況が強いと推察される。一 方小値賀では, 有職者の約 $43 \%$ が第 1 次産業従 事者であり, また第 2 ・3 次産業従事者でも自 営業又は小規模の企業に勤務する人が多く，仕 事上の制約が都市部より少なく, 自己の意識次 第で保健行動を優先できる余地が残されている ように思われる. この点からも小值賀では，上 述のように，文化的自由時間の活用方法を住民 とともに考穴ていくことが有効であると考光る.

生きがいについては，小值賀住民は都市部住 民より生きがいを多くもっており, 特に有職者 においてその傾向がみられた．項目別にみると， 仕事や仕事仲間とのつながりを生きがいとする 人の割合が高かった。少值賀では, 第 1 次産業 從事者はもとより, 自分の仕事の成果が見兄や 
すく，仕事に生きがいをもちやすい状況にある と考えられる. また地域の団体活動, 奉仕活動, 宗教に生きがいを持つ人の割合も小值賀住民の 方が高かった．このことは，小值賀では住民相 互の助け合い精神や先祖を敬ら気持ちが日常生 活の中により多く残っていることを示唆してい る。また小值賀住民では生きがいを多くもって いる人汪ど保健行動を実行していた. 今後地域 の団体活動や奉仕活動のどのような関わりを生 きがいと感じているか，また実際にどの程度関 わっているかなどを調查することによって，保 健行動を促進する方策を見いだしていけるもの と考光る.

社会の都市化は家族, 親族, 近隣などの社会 的支援ネットワークを脆弱化させる ${ }^{12)}$ といわ れているが，今回の調査では，農漁村部である 小值賀住民の方が情緒的支援ネットワークの得 点が低かった．仕事仲間とのつながりや地域の 団体活動への参加及び奉仕活動を生さがいと感 じる人の割合は小值賀住民の方が高いことから 考穴ると, 小值賀住民の方が社会的支援ネット ワークをもっていると考光られ，支援得点の結 果とは一致しない，今回用いた測定用具は支援 源を特定しないものであり，支援源が一人であっ ても得点が高くなることが考穴られ，支援ネッ トワークの地域特性を把握するためには，今後 調査方法を再検討する必要があるだろう.

また重回帰分析の結果，小値賀住民では保健 行動実行度の分散の約 $30 \%$ が 5 つの実行要因で 説明可能であった。このことは，都市部住民に 比べ小值賀住民では, 調査した実行要因に着目 して対象への支援を行らことによって，対象の 保健行動の実行を高める可能性が大きいことを 示している．しかし，5つの要因で説明できる 範囲は限られており，保健行動の実行に影響を 及ぼす他の要因についても今後検討する必要が ある。

\section{3. 本研究の限界と今後の課題}

本研究の対象者は無作為抽出ではないため, 母集団を代表しているとはいえない。特に対象 者の多くが女性であり, 地域全体へ一般化する には限界がある. 今後, 対象者を広げるととも
に, 面接調査, 参加観察などの方法も取り入れ, 保健行動の地域特性をさらに明らかにしていく 必要がある.

\section{V. 結 論}

農漁村部である長崎県小值賀島住民の保健行 動を都市部住民の保健行動と比較した結果, 以 下のことが明らかになった。

1 ) 小值賀島住民は都市部住民より, 保健行動 を実行しており, 特に50歳未満, 有職者で差 がみられた．小值賀島住民は，より規則正し い食事をし, 夜更かしをさけ, 睡眠を十分とっ ていた.

2 ) 小值賀島住民は都市部住民より, 生活行動 の中で保健行動を優先させる態度が強く, 生 きがいを多くもっていた，小值賀島住民は， 仕事, 地域の人との関わり, 宗教をより生き がいとしていた。

3 ）小值賀島住民の保健行動実行度の約 $30 \%$ が 調査した 5 つの実行要因で説明可能であり, 都市部住民より影響が大さかった。 小值賀島 住民では, 他の生活行動より保健行動を優先 させる態度が強い人ほど，生さがいを多くもっ ている人ほど, 保健行動の実行度が高かった.

\section{謝辞}

本研究の調査に際し, 貴重なデータを提供し て下さった住民の皆様, 調査にご協力いただき ました小值賀町診療所田中敏巳所長, 小値賀町 健康センター伊藤千恵子保健婦に心より感謝申 し上げます。また本研究の実施および論文作成 にあたり, 御指導頂きました北里大学看護学部 山本昇教授に深謝致します.

\section{文献}

1) 池田順子, 浅野弘明, 松野喜六, 他 : 京都 府下の食物摂取構造の分析一食品摂取量に よる一, 日本公衆衛生誌, 35 (5), 262-267, 1988.

2 ）坂本むつ子, 小松良子, 河内卓, 他 : 地域 の疾病構造とそこに居住する高齢者の食生 活との関連について, 栄養学雑誌, 45 (1), 23-31, 1987. 
3 ）芳賀文子, 伊藤静子, 沼倉久枝, 他：東北 地方における婦人の食行動および食習慣の 検討一家族形態別比較一，栄養学雑誌， 46 (1) , 15-26, 1988 .

4 ）藤尾順子, 片㴊きょ5子, 大坪藤代, 他 : 長崎県小值賀町における食生活調查(第 1 報)一栄養摂取と 2,3 の食品摂取につい て一, 長崎女子短期大学紀要, 13, 1-10, 1989.

5 ）加藤寛夫, 早渕仁美：日本人と日系米人の 健康と食生活に関する疫学的研究, 栄養学 雑誌, 47 (3), 121-130, 1989.

6 ) 矢野由起, 坂本裕子, 舟橋和夫, 他: 三重 県答志島における主婦の食品摂取量からみ た食生活構造, 栄養学雑誌, 50 (1), 31-42, 1992.

7 ) 笠松隆洋, 吉村典子, 森岡聖次, 他: 和歌 山県民の食生活についての調査研究一栄養 摂取量の地域差について一, 栄養学雑誌, 52 (1) , 13-23, 1994 .

8 ）村上文代：広島住民および在米日系人に関 する栄養学的考察ならびに栄養㨟取状況の 諸種臨床検査成績に及ぼす影響に関する研 究, 広島大学医学雑誌, 36 (4), 563-617, 1988.

9 ）黑木緑, 大坪藤代, 藤尾順子, 他：長崎県 小值賀町における食生活調査 (第 2 報)一栄 養摂取之疲労, 疾病について一, 長崎女子 短期大学紀要, 13,11-16, 1989.

10）渡辺満利子, 山岡和枝 : 大都市男子勤労者 の境界型耐糖能異常之食物摄取状況, 生活 習慣との関連性一人間ドック受診者におけ る断面調査一, 日本公衆衛生誌, 40 (10), 969-979, 1993.

11）岸本拓治, 副澤陽一郎, 阿部美代子, 他 : 隠岐島に打ける漁業従事者の健康実態と保
健活動の課題, 日本公衆衛生誌, 37 (6), 434$441,1990$.

12）宗像恒次, 仲尾唯治, 藤田和夫, 他: 都市 住民のストレスと精神健康度, 精神衛生研 究, 32, 49-68, 1985.

13）杉澤秀博, 奥山正司, 柴田博: 東京都にお ける中年期男子の保健行動の地域比較一予 防的保健行動について一, 日本公衆衛生誌, 41 (11) , 1041-1049, 1994.

14）宗像恒次：最新行動科学からみた健康之病 気, メヂカルフレンド社, pp 54-83, 1996.

15）市川雅教, 吉田節子, 豊川裕之：因子比較 法による複数地域の食物摄取要因の比較, 日本公衆衛生誌, 32 (9), 560-569, 1985.

16）深尾彰, 清水弘之, 前沢政次, 他：質問票 による食習慣調査の再現性に関する検討, 日本公衆衛生誌, 37 (5), 347-352, 1990.

17）渡辺満利子, 山岡和枝, 豊川裕之: 大都市 人間ドッグ受診者における近年の食物摂取 状況と食事嗜好に関する研究, 日本公衆衛 生誌, 39 (5), 259-268, 1992.

18）池田順子, 東あかね, 永田久紀: 食品群摂 取頻度調査結果のスコア化による評価の妥 当性について, 日本公衆衛生誌, 42 (10), 829-842, 1995.

19）内野澄子：人口移動の食生活への影響, 人 口問題研究, 176, 18-32, 1985.

20）今田純雄：食行動への心理学的接近, 人間 行動学講座 2 たべる一食行動の心理学一, 中島義明・今田純雄編, 朝倉書店, pp 10-22, 1996.

21）柴田一男: 労働と健康, 改訂現代生活と健 康, 内山源 - 篠田昭八郎・三井淳蔵編, 家 政教育社, pp 123-132, 1986. 